\title{
The Efficacy of the Application of Mother Tongues Education in Pakistan
}

\author{
* Shah Nawaz Khan, Visiting Professor \\ ** Dr. Abdul Karim Khan, Assistant Professor (Corresponding Author) \\ *** Dr. Ihsan Ullah Khan, Assistant Professor
}

\begin{abstract}
No doubt, the importance of English cannot be denied, but at the same time, mother tongue has also due importance concerning one's culture and understanding basic concepts at schools at primary level. This paper is an attempt to prove the importance of mother tongue as a medium of instruction at the primary level in District Bannu. The data were collected from students' focal groups of fifty classrooms from ten schools. Two questions were asked in each subject from the focus groups to check their concept of the subject. Similarly, among the teachers, thirty respondents were interviewed in the Parents-Teachers Meeting (PTM) to find out their views about the efficacy of mother tongue instructions at the primary level. In this connection, parents were also interviewed. The results showed that among the students whose concept was clear, eighty percent of students were those who were taught in their mother tongue whereas twenty percent of students were those who were taught in English. Again, among the thirty teachers, eighty-five percent felt comfortable with teaching in the mother tongue whereas fifteen percent of teachers showed positive inclination towards teaching in a second language. Lastly, parents also felt at ease with the mother tongue instructions as they conveyed that their children go to school with zeal. Thus, mother tongue instruction proved helpful at the primary level. This study will also prove helpful to other researchers in the future for conducting similar studies in other districts.
\end{abstract}

Keywords: English, Medium of Instruction, Mother Tongue, Pakistan.

Introduction

Pakistan is a multicultural and multilingual country where more than sixty major and small languages are spoken. Rahman, T., \& Knight, T. (1996), however, believe that two languages, namely Urdu and English are used in public and private offices, the education sector, and domains of media. Surprisingly, Urdu is considered as our national language, though it is spoken by just seven percent of the country's population. According to Tariq Rahman (2006), the small languages are under immense strain, some of which are disappearing, while the others are greatly endangered at the expense of others because the government encourages Urdu and English. Punjabi is the most widely spoken language in Pakistan which is spoken by $44.15 \%$ of the population while $14.1 \%$ use Sindhi, $10 \%$ Seraiki, English and Urdu 7\%, Pashto 15.42\%, Balochi 3\%, Hindko 2\%, and Brahui 1\%. Language is a social gift that is passed down from generation to generation over time. Man's memory changes but language does not change, he can lose memory but cannot forget his language. Undoubtedly, language is the most important part of any human being's identity, and therefore it is considered as one of the basic human rights. The status of mother tongues as a source of national identity and valuable cultural heritage cannot be denied.

UNESCO celebrates the International Day of the Mother Tongue every year on 21 February. The principal goal of celebrating this day is to propagate the knowledge about local languages throughout the world. What is the importance and significance of celebrating this day? This question has a historical background.

February 21, 1951, is the historical day when the police opened fire on the students, protesting in East Pakistan. They requested that Bengali may be granted the status of national language. Later in 1956, along with Urdu, Bengali was provided national language status, but the

\footnotetext{
* University of Science \& Technology, Bannu, KP, Pakistan Email: khanshahzeb447@ gmail.com

** Assistant Professor, Department of English \& Applied Linguistics, University of Science \& Technology, Bannu, KP, Pakistan Email: akarim.khan@yahoo.com

*** Department of English, University of Science \& Technology, Bannu, KP, Pakistan Email: ihsanlakki@yahoo.com
} 
students' successful movement drawn the world to an important issue. In November 1999, the United Nations Scientific and Cultural Organization for Education (UNESCO) agreed that 21 February should be known as the International Mother Language Day to protect the endangered languages and spread among the nations, the importance and usefulness of languages. Since 2000, February 21 has been celebrated as International Mother Tongue Day every year. Thus, it is no denying the fact that the importance of the mother tongue is accelerating day by day as it is the basic source of one's identity and culture. It is also a fact that English has entered the very essence of commerce, medicine, sciences, and all sorts of communication that is done through various means such as social media, etc. So, non-native speakers of English must enhance their spoken as well as written efficiency in English which can be done directly and indirectly through exposure to English and which can best be done through teaching various subjects in English. But, it will be better to adopt the mother tongue, at the primary level, as a medium of instruction so that the concept of the children could be made clear.

\section{Statement of the Problem}

Both the teachers and students, at the elementary level in the context of Pakistan, face problems in English as a medium of instruction. Due to poor vocabulary and appropriacy, both the learners and teachers face difficulties in sharing their ideas. No doubt, English is an international language and learning of it is a must but to overcome the difficulty of imparting and understanding information both by teachers and students respectively, it is hoped that if elementary teaching and learning is carried out in mother tongue, then the base of learning would be solid and firm and will be beneficial for learners while pursuing studies at higher levels. In this connection, the research aimed at examining the perceptions of teachers and young-adult learners of the emerging mother language interests regarding the medium of instruction.

\section{Review of the Literature}

Numerous studies have shown significant results in favor of mother-tongue instruction such as Njoroge (2017). This study gave great importance to the influence of the mother tongue. He maintains that after conducting an experimental study in Kenya, he concluded that there was sufficient improvement found regarding understanding the contents taught in the mother tongue. Singleton and Ryan (2004) and Mohanty and Saikia (2008) believe that children beginning school with their second or third language lag behind the children beginning with their mother tongue. It has been a very pervasive misconception that early beginning in English language indicates good schooling and guarantees great achievements in career. Skutnabb-Kangas et al (2009) revealed that "the faith that an early start in English means good education and ensures success in life is a pernicious myth" (p.327).

Jim Cummins (1979) avers the connection between the development of children and their mother tongue. Children who acquire abilities in two or even three languages, according to his findings, grow up to have a better understanding of how to form sentences and utterances.

On the occasion of the 70th anniversary of the Universal Declaration of Human Rights, UNESCO (1953) stated in its strong declaration that 'language-based discrimination cannot be biased against' and also endorsed the 60th Convention regarding disparities in Education, which prevented all biased policies in language-based education discrimination. Thus according to the charter of UNESCO, when more and more languages cease to exist, linguistic diversity is severely threatened. Throughout the world, several people are deprived of their home and birth language education, through which they can communicate easily. Keeping in mind its significance, however, development in education in native language in different and multi-cultural diversity has been achieved with an emergent allegiance to its growth in public life, especially in primary education. Instruction and communication apart from the mother language in school has a severe and adverse impact on the way children learn to think, as well as a major obstacle to their cognitive development. Benson (2004) suggests the effectiveness of the native language, that it can strengthen cultural ties and education, as well as political participation.

Agbedo and Abatu-Abura (2012) maintain that a need-based language policy in the education system encourages schools to use the mother tongue as a medium of instruction as, in this way, the learners' comprehensive capabilities are enhanced. This debate both at formal and informal forums will continue as results will vary from place to place.

\section{Method}

The empirical and methodological approach that directed the said research focused essentially on the connection between the implementation of children's mother language (L1) as well as the 
development of a child's first language scholastic language skills and proficiency. Cummins (1979) supports the concept of integrated native language theories as a medium of instruction, language teaching, multilingual education, the learning of second languages, and the growth of academic languages.

Data for the study were collected from 50 classrooms of 10 primary schools in the public sector. Out of 10 schools, 5 schools were those where the concepts of the students were made clear through native language; while in the rest of the 5 schools English language was used for the clarification of the concept. In each class focal groups were formed. Two questions were asked, in each subject, from the focal group to check their concept in the subject. In addition to that, for the triangulation of data, confirmation of data was made by interviewing the teachers and parents in parent-teaching meetings. After the collection of data, the analysis was made through percentage.

\section{Results}

The analysis revealed that $80 \%$ of students, whose concept in the various topics was clear, belonged to the schools where the medium of instruction was the native language i.e. Pashto; while the remaining $20 \%$ belonged to the schools where the medium of instructions was other than the native language. The following pie-chart best describes the results:

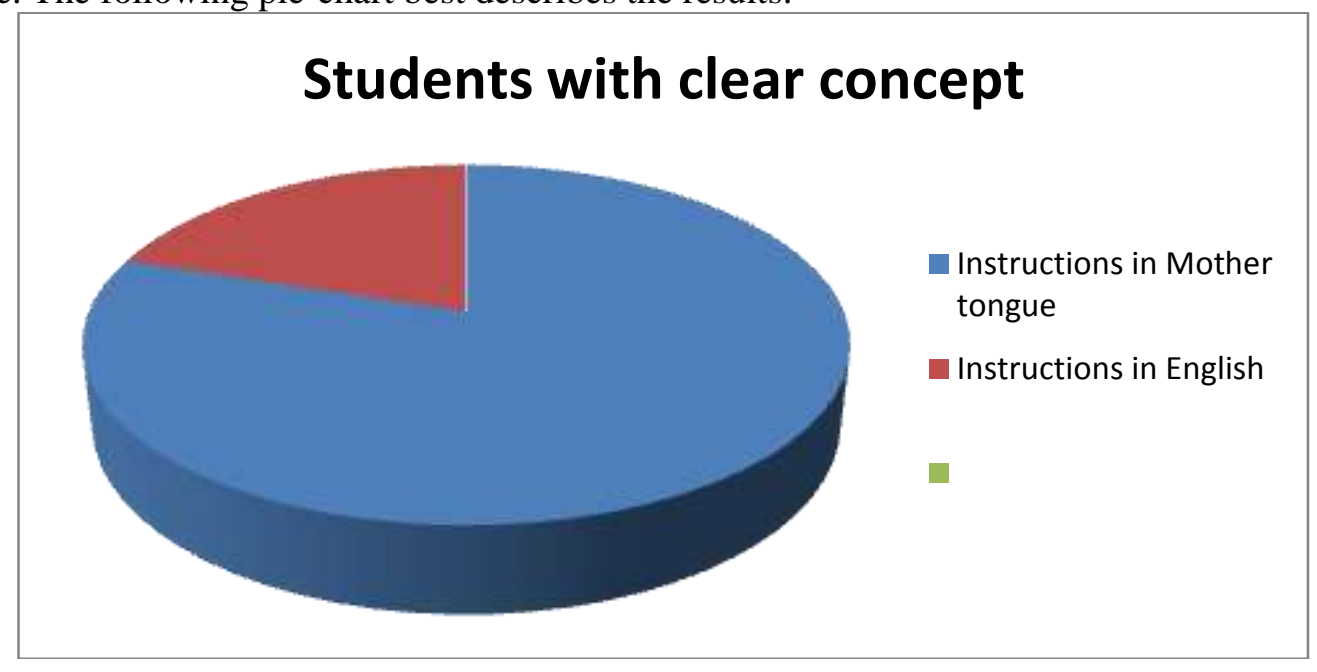

Among the teachers, out of a total of 30 respondents, $85 \%$ of teachers believed that it was extremely easy for them to make the concepts of the students clear in the native language. The remaining $15 \%$ of teachers recorded that they were comfortable with teaching in the second language. This group believed that it was their duty as teachers to make the students learn the second language as well, besides, to make the concepts of the students clear in the subject. The following pie-chart best describes the results:

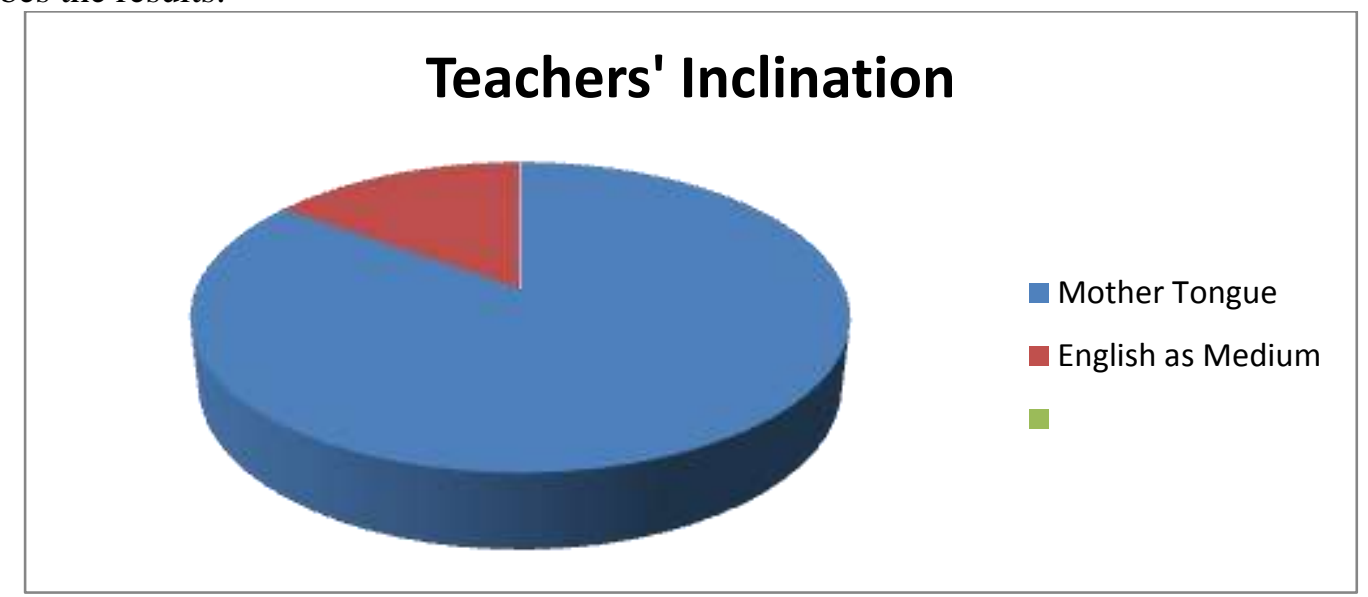

The views of parents were also noted in the parents-teachers meetings on the subject. The parents of those students who were taught in the native language recorded that their children are relaxed in their homes and were very eager to get up early in the morning and go to their schools. On 
the contrary, the parents of the students who were taught in the second language told that they showed hesitation to go to school and were happier when the school was off.

\section{Discussion}

Those who support the mother tongue as a medium of instruction, believe that every word and phrase in the mother tongues embodies national traditions, culture, and mental and spiritual experiences, so they are considered the most effective tool for the survival and promotion of our material and cultural heritage. Moreover, the child retains throughout what they learned from their mothers during childhood.

Every word and phrase in the mother tongues embodies national traditions, culture, and mental and spiritual experiences, so they are considered to be the most effective tool for the survival and promotion of a person's material and cultural heritage. Similarly, with education in the mother tongue, children quickly understand new things, digest them and repeat them fluently when asked. Education in the mother tongue has a positive effect on the educational health of the children, as a result of which they happily run to the educational institution and wait anxiously for the next day after the holiday. It is also very easy for a teacher to teach children in their mother tongue. Mother tongue is an essential element for the mental development of human beings today.

The self-esteem of children is strengthened and reinforced, if there is no significant difference between the language of home and the language of school. Again, young children can quickly attain understanding, mental versatility, and analytical adaptability if it takes place in their home language with which they are already acquainted. It is also straightforward for the teacher to teach the children in their mother tongue and for this, he does not have to work extra hard work and the work of months could be completed in days or weeks. Education in mother tongue helps to encourage and promote the language itself.

Whatever a child learns in childhood, he learns in his mother tongue and acquire all the necessary abilities and capabilities, and needs of the society. Another view is that a further change to English as the medium of instruction in the education process of the child would be quite necessary at some later point. Children can quickly acquire insight and intellectual versatility if their education in their home language. Children's basic cognitive learning seems to be more effective if it begins in a mother tongue that they fully comprehend because children can play a far more productive part in the learning process by sharing and exchanging ideas.

Those teachers who supported the second language as a medium of instruction believed that by learning English as a second language, individuals from other nations will appreciate and value us. English as a langue Franca and a unifying language bring the people of the world together. Children, at an earlier age, learn languages effectively. They claimed that children could not read and write in the language of their mother, so English should be used as a teaching tool. In an understanding and contribution, children in public schools are slower than the children in Elite private schools; and by using English as a medium of learning and application, the gap between both the lower and elite classes can be filled. English is important and necessary due to globalization. They believed that children cannot read and comprehend in the language of their mother's tongue, therefore English should be used as a medium of instruction.

Urdu supporters, as a medium of instruction, believe in the philosophy of one country, one language. They believed within the colonial notion that a country requires a common and coherent political language and it incorporates an incredible impact on policy-makers in numerous places of the globe. They argued that the government could not be succeeded to accept such a multicultural and ethnolinguistic diversity, which is a major force to destabilize the countries. They further expressed that local languages could not express the modern concept.

\section{Conclusion}

To conclude, the use of a second or foreign language as the medium of instruction to help learners attain the highest levels of reading skill in the world has not been accomplished; rather, this has been done in most cases by using the home language of children or a national language. In the early stages of schooling, a child whose mother tongue differs from the curriculum faces problems. The main focus of the teachers should be, at the primary level, laying a solid foundation for the students in various subjects. Their experience showed that not only students but they felt comfortable with the mother tongue. The positive effect of the mother tongue is also recognized by the parents. It is a wellknown fact that developed countries like America, Japan, Russia, including European nations have 
educated their children in their mother tongue and have achieved progress due to their mother tongue education. In 2008 in Pakistan, the government of Khyber Pakhtunkhwa passed a law making mother tongue a compulsory subject at the primary level. Even today, it is a powerful cry that mother tongue is introduced as a compulsory subject up to the level of matriculation rather than primary.

This paper, it is hoped, is going to be an awakening call for the policymakers, and also raise debate among scholars about this important issue of Mother Tongue-Based Education, a debate which may hopefully culminate in the adoption of a language policy that accommodates students from various linguistic backgrounds. Once the usefulness of mother-tongue instruction is explored, it will open up new vistas for the educational learning-teaching process.

\section{References}

Agbedo, C. U., Abatu-Abura, L. I., Krisagbedo, E. C., \& Edward, C. (2012). Mother tongue and Pedagogic disability of the Nigerian School Child. A case for revalorization of indigenous Nigerian languages. Journal of Education and Practice. New York: UK@ iiste. Org pp45-55.

Benson, C. (2004). The importance of mother tongue-based schooling for educational quality. Commissioned study for EFA Global Monitoring Report 2005, Centre for Research on Bilingualism, Stockholm University.

Cummins, J. (1979) Linguistic interdependence and the educational development of bilingual children. Review of Educational Research [online]. 49 (2), pp. 222-251. Available from: http://rer.sagepub.com/content/49/2/222.full.pdf+html [Accessed 26 June 2010].

Mohanty, AK. \& Saikia, J. (2008). Bilingualism and Intergroup Relationship in Tribal and Non-tribal Contact Situations. www.scholarworks.gvsu.edu.

Njoroge, M. C. (2017). The Efficacy of Using Mother Language in the Teaching of Mathematics and Science in Primary Schools: Evidence from Grade One Classrooms in Kenya. https://scholar.google.com.

Singleton. D, \& Ryan. L. (2004). Language Acquisition: Age Factor. https://books.google.com.

Skutnabb-Kangas, T., Phillipson, R., Mohanty, A. K., \& Panda, M. (Eds.). (2009). Social justice through multilingual education. Multilingual Matters.

Rahman, T., \& Knight, T. (1996). Language and politics in Pakistan (p. 320). Karachi: Oxford University Press.

Rahman, T. (2006). Language policy, multilingualism and language vitality in Pakistan. Lesser-known languages of South Asia: Status and policies, case studies and applications of information technology, 73-104.

UNESCO (1953). Vernacular Languages in Education. Paris: UNESCO. 